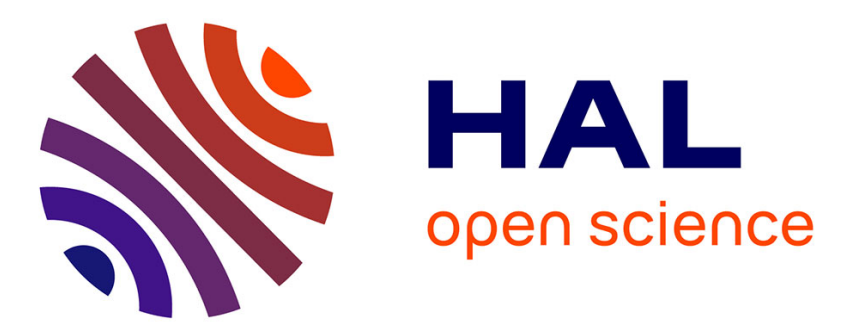

\title{
A Systematic Review of Collaborative Networks: Implications for Sensing, Smart and Sustainable Enterprises
}

Fábio Müller Guerrini, Juliana Suemi Yamanari

\section{- To cite this version:}

Fábio Müller Guerrini, Juliana Suemi Yamanari. A Systematic Review of Collaborative Networks: Implications for Sensing, Smart and Sustainable Enterprises. 20th Working Conference on Virtual Enterprises (PRO-VE), Sep 2019, Turin, Italy. pp.69-80, 10.1007/978-3-030-28464-0_7 . hal-02478761

\author{
HAL Id: hal-02478761 \\ https://hal.inria.fr/hal-02478761
}

Submitted on 14 Feb 2020

HAL is a multi-disciplinary open access archive for the deposit and dissemination of scientific research documents, whether they are published or not. The documents may come from teaching and research institutions in France or abroad, or from public or private research centers.
L'archive ouverte pluridisciplinaire HAL, est destinée au dépôt et à la diffusion de documents scientifiques de niveau recherche, publiés ou non, émanant des établissements d'enseignement et de recherche français ou étrangers, des laboratoires publics ou privés. 


\title{
A Systematic Review of Collaborative Networks: Implications for Sensing, Smart and Sustainable Enterprises
}

\author{
Fábio Müller Guerrini and Juliana Suemi Yamanari \\ São Carlos School of Engineering, University of São Paulo, São Carlos, SP, Brazil \\ (guerrini@sc.usp.br, jusuemi@usp.br)
}

\begin{abstract}
The formation of collaborative networks advocates the efficient sharing of information and knowledge, agile and intelligent decision making for the improvement of operational, financial and organizational performance. Such configuration is motivated by the technological advances, increasing demand for customized products and dynamism characteristic of the digital era. Sensing, Intelligent, and Sustainable Enterprises $(S \wedge 3)$ address a new vision to be disseminated among organizations seeking competitive advantage. Based on the literature on Collaborative Networks and $\mathrm{S}^{\wedge} 3$ Companies, the article proposes to systematically review the state-of-the-art of collaborative networks, identifying challenges and future research opportunities present at the intersection of these two approaches. As a contribution of the research, is presented a conceptual framework based on the main results of the review..
\end{abstract}

Keywords: Collaborative networks; $\mathrm{S}^{\wedge} 3$ Enterprises; Competitiveness

\section{Introduction}

Weichhart et al. (2016) proposed the Sensing, Smart and Sustainable Enterprise, which characterizes a company's sensitive ability to understand its own environment and act in concern with the many collected information, making decisions faster, more efficient and more in order to become competitive and sustainable. Sensing enterprise indicates the ability to anticipate future decisions by capturing multidimensional information, enabling the company to reach and know the different scenarios [2]. Smart enterprise refers to the ability of companies to adapt rapidly to competitive market changes and challenges in an agile way to create and exploit knowledge in response to the opportunities [3]. Sustainable enterprise is associated with environmental, social, economic and ethical concerns [4]. Weichhart et al. (2016) signaled challenges and developments for the $S \wedge 3$ approach to become a reality. $\mathrm{S}^{\wedge} 3$ Enterprises cover a number of domains of knowledge in, among them, business collaboration. The review seeks to answer the main question:

How has the discipline of collaborative networks addressed in recent years the advances of companies in relation to the new requirements of the competitive market?

This review article intends to contribute to knowledge by identifying mechanisms in the context of collaborative networks that inspire companies that seek to become 
$\mathrm{S}^{\wedge} 3$, contributing by identifying the main domains of application, challenges and research approaches.

\section{Methodological Procedures}

According Fischl, Scherrer-Rathje and Friedli (2014), the literature review aims to map, summarize and evaluate the relevant knowledge of a particular subject. The approach used in this research is based on three main steps [6]: planning, conduction and dissemination. In the planning stage, it was identified that $S \wedge 3$ Enterprise need studies on the characterization of the collaboration domain. It was decided to systematically review the concept of "collaborative networks" in search of evidence on the motivators of collaboration. Already in the stage of conducting the study, three databases were selected: Scopus, Web of Science and SciELO. In these databases, the keyword entered was "collabo * network *" with asterisks to contemplate the term and its plural and between quotation marks to search the two words together. The first filter applied in the systematic search was the keyword "collabo * network *" (for Scopus and Web of Science) and "collaborative networks" or "collaborative network" or "collaboration network" (for SciELO) in abstracts, keywords and document titles. The second filter refers to the time limitation, from 2012 to 2017. Because it is an incipient approach $(\mathrm{S} \wedge 3$ Enterprises), it is considered that such a limitation does not negatively affect the quality of the research, since the last years are (1988), which is characterized by intense advances in information and communication technologies (ICTs), internet and social networks [7]. The third filter was the exclusive selection of papers in journals indexed and related to engineering. The 138 selected articles were read in full and the contributions acquired will be exposed in the sequence, in the stage of disclosure of the evidences found. After reading in full the 138 articles, fifteen articles were disregarded in the analysis because they did not present relevant contributions. Therefore, in total, 123 articles contributed to the research. Facing the necessity of synthesis, the paper presents the main results citing directly 75 papers.

In the next item the main motivators of collaboration are discussed, basing the construction of evidence on $\mathrm{S}^{\wedge} 3$ Enterprises and, consequently, the elaboration of a conceptual framework.

\section{Results}

The results are based on the identification of the main motivators of the collaboration, search approach and application field.

\subsection{Motivators of Collaboration}

The main factors that motivate organizations to collaborate are sharing information and knowledge, resources and skills, risks and benefits; growing demand for product variety and customization, dynamicity and market competitiveness, exploration and capture of new business opportunities, innovation, improving business performance, 
rapid advancement of Information and Communication Technologies (ICTs), costs reduction, economic, social and environmental sustainability.

Sharing information and knowledge: The ability to share information and knowledge motivates companies to create collaborative networks [8]. The tools to support sharing are based on information and communication technology (ICT), RFID systems [9], standards-based systems that allows computer-human interaction through a web service [10]. Knowledge management allows the aggregation of different factors used and people in order to improve decision making, adapt to new technologies and share knowledge through collaborative networks [11]. Collaboration with universities, and with suppliers, reflects on the efficiency of innovation through technical communication and knowledge transfer [12]. Technological frontier countries seek incentives to collaborate with other countries investing in research in order to create networks of excellence [13]. In this context, the European Union funds collaborative projects between organizations with the intention of disseminating and eventually creating new knowledge [14]. Clusters are more likely to receive research and development subsidies, benefiting from the ease of access to the knowledge disseminated in this concentration of companies seeking collaboration [15]. Scientists promote the exchange of knowledge in exchange for recognition in the scientific environment [16]. The process about knowledge requires adequate strategies, tools and methods, as well as definitions of the consequences and needs of collaborative partnerships [17].

Sharing of resources and skills: The manufacturing industry faces challenges and the principle of business collaboration helps to share resources and competences [18], reflecting the capture of business opportunities [19], profitability of the company [17], access to information and knowledge and the company's reputation [20]. An entrepreneur faces uncertainties such as resource capacity that can be viable through collaboration [21]. Resource sharing fosters the search for collaboration [22].

Risk and benefit sharing: The investment in capacity expansion is the uncertainty that motivates a decision maker to collaborate with other companies, since the technologies suffer a rapid obsolescence [23]. R\&D projects are motivated to form partnerships to share risks and benefits [24], specifically the initial phase of product development. Online collaboration platform can encourage risk management more efficiently and effectively, especially in cases with diminished technical, financial and human resources [25].

Growing demand for product variety and customization: The customization of products enables aggregation of value, quality of service and increase in sales volume [26]. The growing demand for customized products generates the stakeholders need for knowledge [27]. Collaboration between companies is a mechanism to manage the growing demand for services associated with production processes [28]. The e-work encompasses computer-supported collaborative operations in distributed organizations can serve as a tool to assist traditional enterprises [29].

Dynamicity and market competitiveness: The complexity and dynamism of the market are a highly competitive business environment [30]. Intense changes such as rapid technological development, internationalization of the market and trade, as well as socioeconomic and political issues have affected society and business [31]. Collaborative networks improve the sociability and usability of ICTs [32], and are considered effective for geographic and social issues, as it enables a trust relationship 
between partners, establishing common policies, infrastructure and interoperability [33]. Market demands interfere with the harmonization and interoperability of collaborative networks [34]. The dynamic environment reflects in the growing number of publications, conferences, responsibilities and impact society as a whole [35]. It is necessary to renew, expand, adapt and modify products and processes [36]. Consumers demand quality products with agility and cost-effectiveness [37]. Collaboration networks allow the management of complex and dynamic systems [38]. During the management of these systems, the loss of knowledge during product development should be avoided [39]. Social capital as a key resource for collaborative practices [40].

Exploration and capture of new business opportunities: Collaboration allows capturing new business opportunities. The collaborative networks provide conditions in new and unexpected business opportunity [41]. In the academic context, a collaborative can facilitate access to resources [42]. Collaboration allows the increase of visibility and the recognition of own competences [16]. The search for collaborative partners is an important channel for winning new clients [43].

Innovation: Collaborative networks have six times the capacity to develop innovation compared to organizations that operate individually [44]. Companies that collaborate technologically are more likely to generate product innovations and specifically radical innovations, and the larger the company, the more likely it is to generate innovations [36]. Public research funding facilitates the production of knowledge and is a key element to develop technology innovations [45]. Knowledge management, trust building and communication among partners in a collaborative network are essential factors for innovation [46]. The failure to harness the knowledge embedded in the collaborative network is detrimental to the innovation [47].

Improving business performance: Several organizations seek to stablish collaboration networks to gain agility, complement activities, competitiveness, and improve resources, gain innovation power, flexibility, efficiency and effectiveness of operational activities [48]. The collaborative scenario encompasses criteria, mechanisms, and decisions that improve business performance [18]. Collaboration is proven an effective strategy to improve service levels, process stability and the utilization of productive resources [49]. Collaboration among researchers aims to improve the quality of research, increase scientific productivity [50] and longevity [51]. In R\&D projects, collaboration fosters the exchange of knowledge, sharing of resources and costs among employees, improving expected results, and industry performance [52]. In humanitarian projects, intergovernmental collaborative networks improve the quality of services provided to clients, as well as optimize the use of resources and reduce expenses [53]. Collaborative networks are motivated by the urgency to rescue lives, thus advocating for efficiency and interoperability in services[54]. In the academic and industrial contexts, the motivation is associated with the search for improvement of business performance and, consequently, competitiveness [55].

Rapid advancement of ICTs: The organizations in collaborative networks aim to meet the needs of the market [56], such as virtual organizations and regional clusters [57]. ICTs support collaboration and the breakdown of geographical barriers of the global market [58]. ICTs accumulate knowledge from different domains to leverage the collaborative relationship [59]. ICTs are relevant to help manage the highly 
unpredictable nature of demand and the short lead times associated with the products [27]. Network technologies enable the harmonization of internal and external communications [59]. The demand for constant technological improvement and advances capable faces new challenges such as interoperability [37].

Costs reduction: The importance of the efficient structuring of the collaborative network so that the costs of adopting this strategy do not exceed the desired benefits [60]. Uncertainties on the global stage drive collaboration to reduce costs, improve trust, and meet consumer demand [61]. The reduction of transportation costs through the formation of collaborative networks among suppliers [62].

Economic, social and environmental sustainability: Global warming as a factor that motivates companies to improve their environmental and social reputation [63]. Managers have been attacking the question of environmental sustainability for the development of products, intensifying the collaborative partnerships [64]. There is a trend of international collaborative partnerships for mitigating climate change [65]. Collaborative efforts contribute to the reduction / minimization of environmental impacts. Network sustainability requires strategic planning as well as a common understanding of how partners collaborate, and interact with society and the physical environment [31].

\subsection{Search Approaches}

The first approach is conceptual. Durugbo and Riedel (2013) proposed a conceptual model to assess the readiness of organizations in collaborative networks to service the product / service system, with multiple case study in four different sectors. Grilo et al. (2013) proposed a model for business interoperability in the context of collaborative networks. Kumar (2014) proposed a framework for knowledge management, which could serve as an early warning system to avoid excessive product recalls. This framework was approached in a practical study in the food sector. Lyons et al. (2013) developed a knowledge-based framework to demonstrate how different collaborative networks can support product variety and customization.

The second approach is bibliographic review. Di Cagno, Fabrizi and Meliciani (2014) conducted a study on R \& D projects and concluded that participation in projects funded by the European Union is an important channel for knowledge transfer. Karimi and Khalilpour (2015) developed a bibliometric review, considering the years 1980 to 2013, on the evolutionary trend of international carbon capture and storage collaborations, analyzing the collaborative network of the countries that publish on this subject. Kim and Perez (2015) considered the years from 1997 to 2012 to carry out a bibliometric review of industrial ecology.

The third approach was the proposition of models, frameworks, prototypes, systems, architectures, etc., in a conceptual or mathematical way, without practical applications. Li and Du (2015) proposed a framework to support the sharing of data among all the participants of a collaborative network, proposing the cloud as the main support tool. This framework is an intelligent intermediary system that helps companies to search, question and recommend potential collaborators.

Surveys and case studies were addressed in fewer investigations. Macke et al. (2013) conducted a survey to identify the relationship between the elements of 
interorganizational social capital and the competitiveness of the collaborative network. Dias and Escoval (2012) also used the survey to identify the main pillars of innovation in hospitals and concluded that external collaboration is the main driver of innovation, while technology behaves as a mechanism that facilitates innovation in hospitals. The case study was used in the research of Saetta, Tiacci and Cagnazzo (2013), where they presented the first organization that adopted the model of Virtual Development Office. Boehm and Hogan (2014), in turn, conducted a qualitative case study to analyze collaborative networks between universities and industries.

In summary, approximately $55 \%$ of the selected studies proposed models, architectures, prototype frameworks or systems, considering both the studies that applied in a real case and those that did not apply in a real case.

\subsection{Fields Application}

Fields application are diverse, however, the intention to systematize their occurrence is to elucidate possible applications within the scope of $\mathrm{S}^{\wedge} 3$ Enterprise. Approximately $34 \%$ of studies were performed without specifying a sector. These studies usually present problems and solutions without necessarily associating them to a given field. Chen et al. (2013) proposed a collaborative network security management system that can identify and treat new distributed attacks more quickly and effectively. Huang et al. (2016), in turn, studied how much regulatory pressure and customer pressure affect the organizations' environmental decisions.

The studies about collaborative networks in the academic context have been quite frequent. Boehm and Hogan (2014) investigated the role of the lead researcher in collaborative research projects and empirically validated the entrepreneurial role in building collaborative networks. Chakraborty et al. (2015) proposed two classification models to predict at the beginning of a researcher's career, how long the group to which it belongs will remain active and how productive it will be. Other studies focused on R \& D, technology, virtual organization and other sectors. Arriagada and Alarcón (2014) proposed a model to develop management strategies and maturation of knowledge applied to civil construction. Baek et al (2015) proposed a framework for the design of collaborative services in agricultural communities.

Seventeen publications have specified the field of study, however, were unique in addressing such a sector. Studies were carried out on start-ups in industry: auto parts, state environmental agencies, silk, malting, wine, bio-pharmaceutical, furniture, consultancies, and humanitarian organization, among others. This diversity of fields in the framework of collaborative networks motivates the conduction of studies on $\mathrm{S}^{\wedge} 3$ Enterprise. Regardless of the industry or focus of the research, companies and universities are generally looking for collaborative relationships to meet the new challenges imposed by current business models.

\section{Results Systematization}

The systematic review of a widespread and consolidated discipline (collaborative networks) sought to detect how much the researchers have directed, albeit indirectly, their respective research to the new vision mentioned above. It was possible to highlight the main motivators for the formation of collaborative networks: sharing of 
information and knowledge; resources and skills; risks and benefits; increasing demand for variety of products and customization; dynamism and competitiveness of the market; exploration and capture of new business opportunities; innovation; improving business performance; ICTs; cost reduction and economic, environmental and social sustainability. The main challenges identified by the researchers were: trust among partners; the interoperability of the information systems of the partners involved; the stage of selecting the collaborative partners; the alignment and clear definition of strategies and objectives; ensuring the security of data and information shared over the internet or other informational system.

Figure 1 presents a conceptual framework contemplating the challenges and opportunities identified in the systematic review with the objective of organizing and facilitating the understanding of the objectives intended in the work, as well as contribute with literature and future practical work on the theme. The study of collaborative networks was adopted through the intersections with the $\mathrm{S}^{\wedge} 3$ approach.

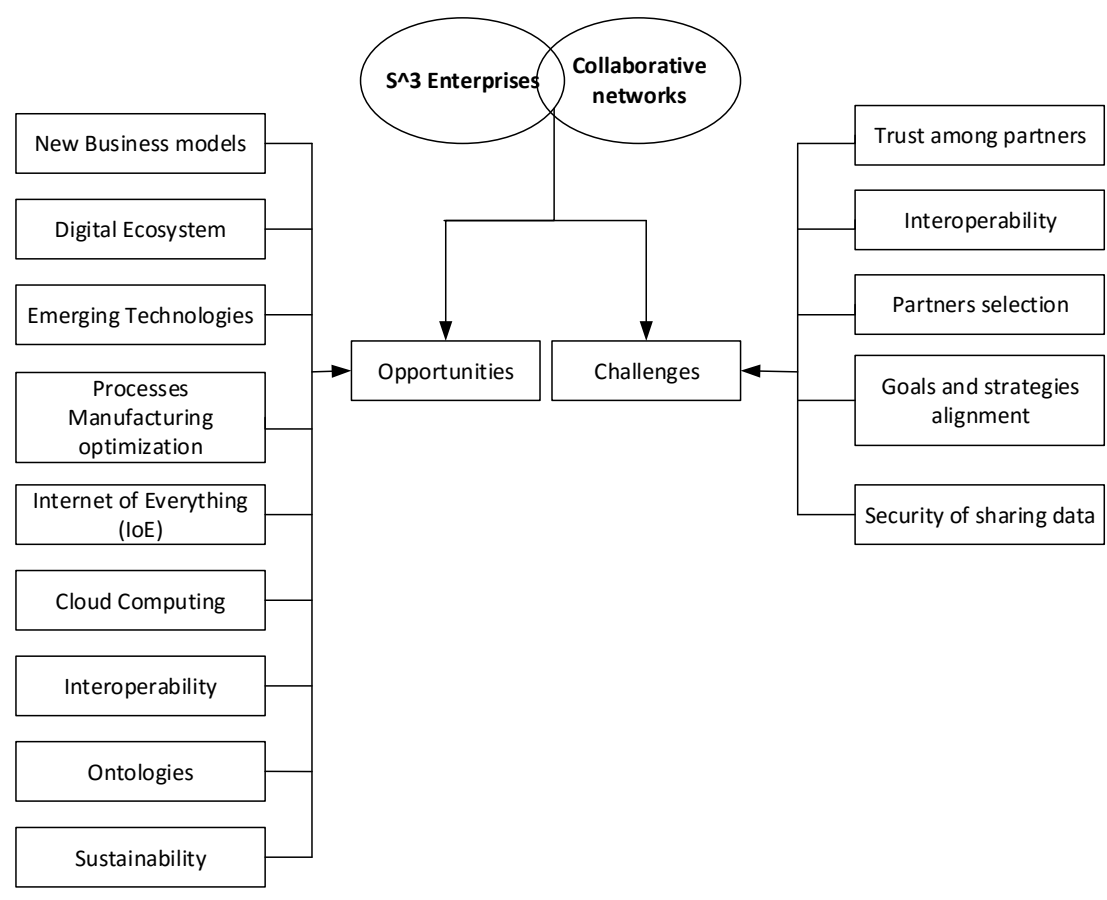

Figure 1: Conceptual Framework of Collaborative Networks and Enterprises $\mathrm{S}^{\wedge} 3$

\section{Conclusions}

The systematic review on collaborative networks was carried out because it is a consolidated subject in the literature and that meets the research gaps identified in the work of Weichhart et al. (2016). The approach of a mature discipline aims to guide the development of the new paradigm discussed in the present study, $\mathrm{S} \wedge 3$ Enterprise. 
The research sought to identify the main motivators, research approaches, most frequent application domains and the list of countries that published the most, for the construction of a conceptual framework with the main challenges and opportunities of collaborative networks and $\mathrm{S}^{\wedge} 3$ Enterprise.

Motivators represented the reasons why companies seek collaboration, and consequently the benefits they seek are implicitly associated. It is worth mentioning that they are implied in the proposed framework, since they were essential for understanding the challenges and opportunities of the areas under study. The most common research approaches, application domains, and the list of countries that most published on the subject were complements that sought to reinforce the idea that collaborative networks are comprehensive and effective strategies for addressing aspects of the digital age.

However, although collaborative networks have advantages, they also have internal limitations such as the availability of resources (physical, human, organizational and financial) and the ability to coordinate them in an integrated way; external constraints expressed by institutional factors governed by rules and conduits in the network operating environment; and associated challenges such as developing trust between partners, interoperability of information systems, selection of collaborative partners, alignment and clear definition of strategies and objectives among all stakeholders, ensuring data security and information shared over the internet or other informational system.

The systematic review allowed us to identify some opportunities in the intersection of collaborative networks and $\mathrm{S} \wedge 3$ Enterprise, such as: the need to develop new business models; the fostering of a digital ecosystem; the development and / or adaptation of emerging technologies; the optimization of manufacturing processes; the exploration of the aspects brought by the internet of everything; the use of cloud computing; the development of interoperable systems; the elaboration of ontologies, architectures, models, frameworks that support the development of the disciplines in question; and sustainable development in the economic, social and environmental aspects of business.

\section{References}

1. Weichhart, G., Molina, A., Chen, D., Whitman, L. E., Vernadat, F. Challenges and current developments for sensing, smart and sustainable enterprise systems. Comp in Ind, 79, 34--46 (2016)

2. Ferro-Beca, Sarraipa, J., Agostinho, C., Gigante, F., Jose-Nunez, M., Jardim-Gonçalves, R. A framework for enterprise context analysis based on semantic principles. Comp Sc and Inf Sys, 12, 3, 931--960 (2015)

3. Filos, E. Smart organizations in the digital age. In: Mezgar, I. (Ed.). Integration of ICT in smart organizations. Idea Group Publishing, London (2006)

4. Mauricio-Moreno, H., Miranda, J., Chavarría, D., Ramírez-Cadena, M., Molina, A. Design S3-RF (Sustainable x Smart x Sensing - Reference Framework) for the Future Manufacturing Enterprise. IFAC-PapersOnLine, 48, 3, 58--63 (2015)

5. Fischl, M. C.; Scherrer-Rathje, M.; Friedli, T. Digging deeper into supply risk: a systematic literature review on price risks. Supply Chain Management: an International Journal, v. 19, n. 5/6, p. 480-503, 2014. 
6. Tranfield, D.; Denyer, D.; Smart, P. Towards a Methodology for Developing Evidenceinformed Management Knowledge by Means of Systematic Review. British Journal of Management, v. 14, n. 3, p. 207-222, 2003.

7. Fornasiero, R. et al. Implementation of customization strategies in collaborative networks through an innovative Reference Framework. Production Planning \& Control, v. 27, n. 14, p. 1158-1170, 2016.

8. Jayaram, J.; Pathak, S. A holistic view of knowledge integration in collaborative supply chains. International Journal of Production Research, v. 51, n. 7, p. 1958-1972, 2013.

9. Quetti, C.; Pigni, F.; Clerici, A. Factors affecting RFId adoption in a vertical supply chain: the case of the silk industry in Italy. Production Planning \& Control, v. 23, n. 4, p. 315-331, 2012.

10. Lin, H. W. et al. Design of a Global Decision Support System for a manufacturing SME: Towards participating in Collaborative Manufacturing. International Journal of Production Economics, v. 136, n. 1, p. 1-12, 2012.

11. Kumar, S. A knowledge based reliability engineering approach to manage product safety and recalls. Expert Systems with Applications, v. 41, n. 11, p. 5323-5339, 2014.

12. Huang, $\mathrm{X}-\mathrm{X}$. et al. The relationships between regulatory and customer pressure, green organizational responses, and green innovation performance. Journal of Cleaner Production, v. 112, p. 3423-3433, 2016.

13. Di Cagno, D.; Fabrizi, A.; Meliciani, V. The impact of participation in European joint research projects on knowledge creation and economic growth. Journal of Technology Transfer, v. 39, n. 6, p. 836-858, 2014

14. Protogerou, A.; Caloghirou, Y.; Siokas, E. Twenty-five years of science-industry collaboration: The emergence and evolution of policy-driven research networks across Europe. Journal of Technology Transfer, v. 38, n. 6, p. 873-895, 2013.

15. Broekel, T.; Fornahl, D.; Morrison, A. Another cluster premium: Innovation subsidies and R\&amp;D collaboration networks. Research Policy, v. 44, n. 8, p. 1431-1444, 2015.

16. Welch, E. W.; Jha, Y. Network and perceptual determinants of satisfaction among science and engineering faculty in US research universities. Journal of Technology Transfer, v. 41, n. 2, p. 290-328, 2016.

17. Swarnkar, R. et al. A framework for collaboration moderator services to support knowledge based collaboration. Journal of Intelligent Manufacturing, v. 23, n. 5, p. 20032023, 2012.

18. Liotta, G.; Kaihara, T.; Stecca, G. Optimization and Simulation of Collaborative Networks for Sustainable Production and Transportation. IEEE Transactions on Industrial Informatics, v. 12, n. 1, p. 417-424, 2016.

19. Hsieh, F. S.; Lin, J. B. Context-aware workflow management for virtual enterprises based on coordination of agents. Journal of Intelligent Manufacturing, v. 25, n. 3, p. 393-412, 2014.

20. Michaelides, R. et al. Collaboration networks and collaboration tools: a match for SMEs? International Journal of Production Research, v. 51, n. 7, p. 2034-2048, 2013.

21. Leung, R. C. Networks as sponges: International collaboration for developing nanomedicine in China. Research Policy, v. 42, n. 1, p. 211-219, 2013.

22. De Prato, G.; Nepelski, D. Global technological collaboration network: network analysis of international co-inventions. Journal of Technology Transfer, v. 39, n. 3, p. 358-375, 2014.

23. Renna, P. Capacity investment decision by Monte Carlo approach in a cooperation network. International Journal of Production Research, v. 51, n. 21, p. 6455-6469, $2013 \mathrm{a}$.

24. Bojanowski, M.; Corten, R.; Westbrock, B. The structure and dynamics of the global network of inter-firm R\&D partnerships 1989-2002. Journal of Technology Transfer, v. 37, n. 6, p. 967-987, 2012. 
25. Effio, D. G. et al. A Look at State-Level Risk Assessment in the United States: Making Decisions in the Absence of Federal Risk Values. Risk Analysis, v. 33, n. 1, p. 54-67, 2013.

26. Cheikhrouhou, N.; Pouly, M.; Madinabeitia, G. Trust categories and their impacts on information exchange processes in vertical collaborative networked organisations. International Journal of Computer Integrated Manufacturing, v. 26, n. 1-2, p. 87-100, 2013.

27. Lyons, a. C. et al. The application of a knowledge-based reference framework to support the provision of requisite variety and customisation across collaborative networks. International Journal of Production Research, v. 51, n. 7, p. 2019-2033, 2013.

28. Zhang, H. K. et al. Promoting efficient communications for high-speed railway using smart collaborative networking. IEEE Wireless Communications, v. 22, n. 6, p. 92-97, 2015 .

29. Zhong, H.; Ozsoy, E.; Nof, S. Y. Co-Insights framework for collaborative decision support and tacit knowledge transfer. Expert Systems with Applications, v. 45, p. 85-96, 2016.

30. Cao, Q.; Thompson, M. A.; Triche, J. Investigating the role of business processes and knowledge management systems on performance: A multi-case study approach. International Journal of Production Research, v. 51, n. 18, p. 5565-5575, 2013.

31. Maccarthy, B. L.; Jayarathne, P. Sustainable collaborative supply networks in the international clothing industry: a comparative analysis of two retailers. Production Planning \& Control, v. 23, n. 4, p. 252-268, 2012.

32. Durugbo, C. Collaborative networks: A systematic review and multi-level framework. International Journal of Production Research, v. 54, n. 12, p. 3749-3776, 2016.

33. Noran, O. Collaborative networks in the tertiary education industry sector: A case study. International Journal of Computer Integrated Manufacturing, v. 26, n. 1-2, p. 29-40, 2013.

34. Jardim-Goncalves, $R$. et al. Reference framework for enhanced interoperable collaborative networks in industrial organisations. International Journal of Computer Integrated Manufacturing, v. 26, n. 1-2, p. 166-182, 2013.

35. Sochat, V. V. AuthorSynth: A collaboration network and behaviorally-based visualization tool of activation reports from the neuroscience literature. Frontiers in Neuroinformatics, v. 9, 2015.

36. Minguela-Rata, B.; Fernandez-Menendez, J.; Fossas-Olalla, M. Cooperation with suppliers, firm size and product innovation. Industrial Management \& Data Systems, v. 114, n. 3, p. 438-455, 2014.

37. Moghaddam, M.; Nof, S. Y. The collaborative factory of the future. International Journal of Computer Integrated Manufacturing, v. 30, n. 1, p. 23-43, 2015.

38. Lelah, A. Et Al. Collaborative network with SMEs providing a backbone for urban PSS: a model and initial sustainability analysis. Production Planning \& Control, v. 23, n. 4, p. 299-314, 2012

39. Shankar, R. Et Al. A collaborative framework to minimise knowledge loss in new product development. International Journal of Production Research, v. 51, n. 7, p. 20492059, 2013.

40. Macke, J. et al. Social capital in collaborative networks competitiveness: the case of the brazilian wine industry cluster. International Journal of Computer Integrated Manufacturing, v. 26, n. 1-2, p. 117-124, 2013.

41. Taticchi, P. et al. A management framework for organisational networks: A case study. Journal of Manufacturing Technology Management, v. 23, n. 5, p. 593-614, 2012.

42. Sabatier, M.; Chollet, B. Is there a first mover advantage in science? Pioneering behavior and scientific production in nanotechnology. Research Policy, v. 46, n. 2, p. 522-533, 2017. 
43. Jansson, K.; Karvonen, I. Using CNOs in international marketing and outbound logistics. Cogent Engineering, v. 1, n. 1, 2014.

44. Dias, C.; Escoval, A. The open nature of innovation in the hospital sector: The role of external collaboration networks. Health Policy and Technology, v. 1, n. 4, p. 181-186, 2012.

45. Beaudry, C.; Allaoui, S. Impact of public and private research funding on scientific production: The case of nanotechnology. Research Policy, v. 41, n. 9, p. 1589-1606, 2012.

46. Guan, J.; Zhang, J.; Yan, Y. The impact of multilevel networks on innovation. Research Policy, v. 44, n. 3, p. 545-559, 2015.

47. Shankar, R. Et al. A collaborative framework to minimise knowledge loss in new product development. International Journal of Production Research, v. 51, n. 7, p. 2049-2059, 2013.

48. Saetta, S.; Tiacci, L.; Cagnazzo, L. The innovative model of the Virtual Development Office for collaborative networked enterprises: the GPT network case study. International Journal of Computer Integrated Manufacturing, v. 26, n. 1-2, p. 41-54, 2013.

49. Moghaddam, M.; Nof, S. Y.; Menipaz, E. Design and administration of collaborative networked headquarters. International Journal of Production Research, v. 54, n. 23, p. 7074-7090, 2016.

50. Kim, H.; Jung, W. S. Bibliometric Analysis of Collaboration Network and the Role of Research Station in Antarctic Science. Industrial Engineering and Management Systems, v. 15 , n. 1, p. 92-98, 2016.

51. Chakraborty, T.; Ganguly, N.; Mukherjee, A. An author is known by the context she keeps: significance of network motifs in scientific collaborations. Social Network Analysis and Mining, v. 5, n. 1, p. 1-21, 2015.

52. Guan, J. et al. Does country-level R\&D efficiency benefit from the collaboration network structure? Research Policy, v. 45, n. 4, p. 770-784, 2016.

53. Tchouakeu, L. M. N. et al. Humanitarian inter-organisational collaboration network: Investigating the impact of network structure and information and communication technology on organisation performance. International Journal of Services, Technology and Management, v. 19, n. 1-3, p. 19-42, 2013.

54. Noran, O. Collaborative disaster management: An interdisciplinary approach. Computers in Industry, v. 65, n. 6, p. 1032-1040, 2014.

55. Zhang, F. Q. et al. Modeling and analyzing of an enterprise collaboration network supported by service-oriented manufacturing. Proceedings of the Institution of Mechanical Engineers Part B-Journal of Engineering Manufacture, v. 226, n. B9, p. 15791593, 2012.

56. Andrés, B.; Poler, R. Relevant problems in collaborative processes of non-hierarchical manufacturing networks. Journal of Industrial Engineering and Management, v. 6, n. 3 SPL.ISS, p. 723-731, 2013.

57. Renna, P. Decision model to support the SMEs' decision to participate or leave a collaborative network. International Journal of Production Research, v. 51, n. 7, p. 19731983, 2013b.

58. Cardoso, T.; Camarinha-Matos, L. M. Pro-Active Service Ecosystem Framework. International Journal of Computer Integrated Manufacturing, v. 26, n. 11, p. 1021-1041, 2013.

59. Durugbo, C. Managing information for collaborative networks. Industrial Management and Data Systems, v. 114, n. 8, p. 1207-1228, 2014.

60. Kandjani, H.; Bernus, P.; Wen, L. Reducing the structural complexity and transaction cost of collaborative networks using extended axiomatic design theory and virtual brokerage. Concurrent Engineering Research and Applications, v. 22, n. 4, p. 320-332, 2014. 
61. Andres, B.; Sanchis, R.; Poler, R. A Cloud Platform to support Collaboration in Supply Networks. International Journal of Production Management and Engineering, v. 4, n. 1, p. 5-13, 2016.

62. Paltriccia, C.; Tiacci, L. Supplying networks in the healthcare sector A new outsourcing model for materials management. Industrial Management \& Data Systems, v. 116, n. 8, p. 1493-1519, 2016.

63. Jaegler, A.; Burlat, P. Carbon friendly supply chains: a simulation study of different scenarios. Production Planning \& Control, v. 23, n. 4, p. 269-278, 2012.

64. Dangelico, R. M.; Pontrandolfo, P.; Pujari, D. Developing Sustainable New Products in the Textile and Upholstered Furniture Industries: Role of External Integrative Capabilities. Journal of Product Innovation Management, v. 30, n. 4, p. 642-658, 2013.

65. Karimi, F.; Khalilpour, R. Evolution of carbon capture and storage research: Trends of international collaborations and knowledge maps. International Journal of Greenhouse Gas Control, v. 37, p. 362-376, 2015.

66. Durugbo, C.; Riedel, J. C. K. H. Readiness assessment of collaborative networked organisations for integrated product and service delivery. International Journal of Production Research, v. 51, n. 2, p. 598-613, 2013.

67. Grilo, A. et al. Construction collaborative networks: the case study of a building information modelling-based office building project. International Journal of Computer Integrated Manufacturing, v. 26, n. 1-2, p. 152-165, 2013.

68. Kim, J.; Perez, C. Co-Authorship Network Analysis in Industrial Ecology Research Community. Journal of Industrial Ecology, v. 19, n. 2, p. 222-235, 2015.

69. Li, K.; Du, T. C. Building a boundary-spanning service for coopetition. Expert Systems with Applications, v. 42, n. 22, p. 8413-8422, 2015.

70. Saetta, S.; Tiacci, L.; Cagnazzo, L. The innovative model of the Virtual Development Office for collaborative networked enterprises: the GPT network case study. International Journal of Computer Integrated Manufacturing, v. 26, n. 1-2, p. 41-54, 2013.

71. Boehm, D. N.; Hogan, T. 'A jack of all trades': The role of PIs in the establishment and management of collaborative networks in scientific knowledge commercialisation. Journal of Technology Transfer, v. 39, n. 1, p. 134-149, 2014.

72. Chen, Y. et al. Evolution of regional scientific collaboration networks: China-Europe emerging collaborations on nano-science. International Journal of Technology Management, v. 63, n. 3-4, p. 185-211, 2013.

73. Chakraborty, T.; Ganguly, N.; Mukherjee, A. An author is known by the context she keeps: significance of network motifs in scientific collaborations. Social Network Analysis and Mining, v. 5, n. 1, p. 1-21, 2015.

74. Arriagada, D. R. E.; Alarcón, C. L. F. Knowledge management and maturation model in construction companies. Journal of Construction Engineering and Management, v. 140, n. 4, 2014.

75. Baek, J. S.; Meroni, A.; Manzini, E. A socio-technical approach to design for community resilience: A framework for analysis and design goal forming. Design Studies, v. 40, p. $60-84,2015$. 